\title{
Etos Kerja Islam dalam Era Informasi
}

\author{
Oleh : Chairil Anwar
}

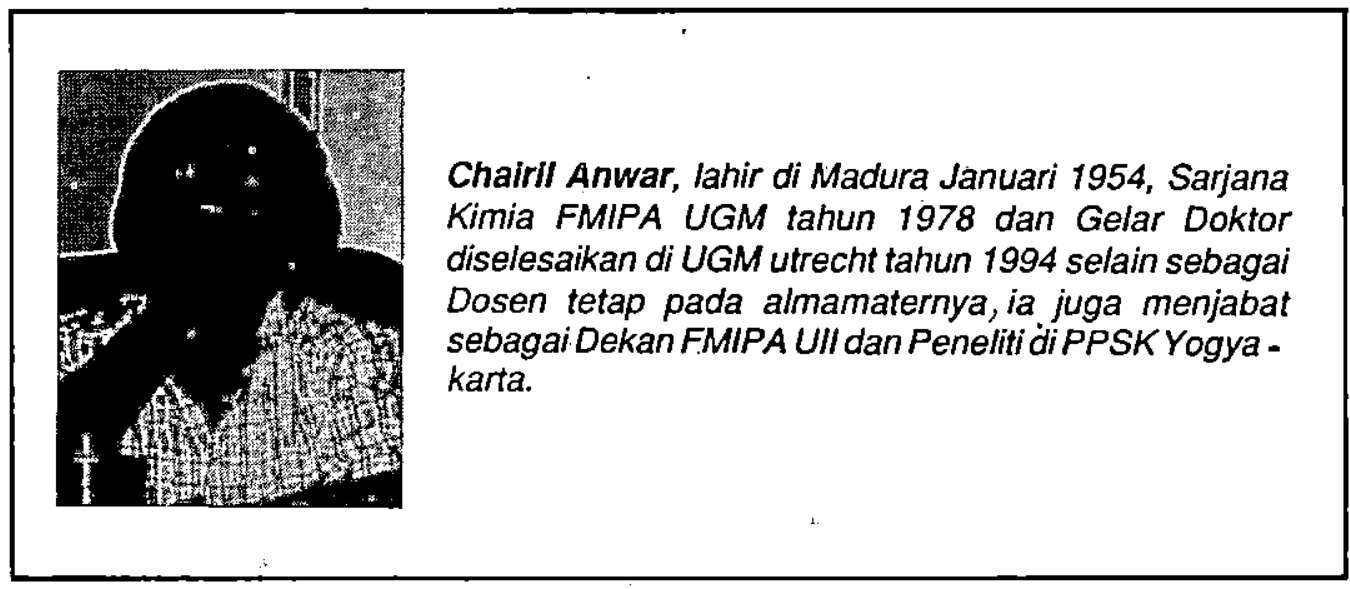

Cyberspace is the land of knowledge and the exploration of that land can be a civilization's truest, highest calling.

Magna Carta

The character of civil society and its intermediate associations, rooted as it is in nonrational factors like culture, relegion, tradition, and other premodern sources, will be key to the success of modern societes in a global economy.

F. Fukuyama (Foreign Affairs, Sept.l Oct.95)

\section{Pendahuluan}

Pada setiap bulan Ramadhan terutama dua tahun terakhir ini kita menjumpai suatu acara yang sangat diminati oleh kaum muda. Itulah forum agama Islam yang diadakan oleh radio maupun TV swasta. Salah satu daya tarik dari acara tersebut adalah karena pendengar atau pemirsa dapat terlibat langsung dalam dialog melalui telepon. Kemudian secara rutin hal itu berkembang tidak hanya masalah keagamaan melainkan juga psikologi, politik dan hiburan. Bahkan acara kuis jari-jari yang diselenggarakan oleh RCTI menarik peminat yang luar biasa seperti yang nampak dari tumpukan kartu pos dan jam penayangan pada prime time. Acara radio maupun TV dimanapendengar/ pemirsa terlibat langsung (interactive) merupakan fenomena yang relatif baru. Begitu pula tentang telekonprensi antara seorang pembicara di New York yang jauhnya ribuan kilometer dengan peserta di Jakarta. Hal ini dimungkinkan berkat perkembangan teknologi komunikasi.

Bagi para pengguna jasa bank dikenal adanya layanan on-line, ATM (automated tellermachine) atau yang lebih dulu populer adalah credit card. Nasabah bank kemana- 
mana tidak perlu membawa uang dalam jumlah banyak, cukuplah buku bank atau kartu. Cara yang mudah dan aman semacam itu dapat terjadi karena adanya teknologi komunikasi yang digabung dengan komputer.

Suatu saat Yasser Arafat ketika masih di pengasingan pemah ditanya wartawan. Bagaimana anda berhubungan dengan ṡtaf anda di Palestina atau di negara lainnya? Arafat kemudian menunjuk suatu mesin kecil yang selalu menemaninya di manapun ia berada. Itulah the mighty fax machine. Mesin itulah yang menghubungkan Arafat dengan para pembantunya walaupun ia senantiasa dilindungi jiwanya dari kejaran Mosad maupun musuh-musuhnya yang lain.

Seorang konglomerat yang memiliki pesawat pribadi dan lebih dari tujuh puluh persen dari waktu hidupnya dihabiskan di perjalanan tidak merasa khawatir bahwa dia akan ketinggalan informasi tentang perusahaannya yang tersebar di seantero dunia. Dia dapat mengontrol dan memantau semua perusahaannya melalui alat komunikasi, baik dengan teleks, telepon mobil, mesin faksimil atau jaringan komputer global (internet).

Perang Teluk Kedua antara Irak dengan AS dan sekutunya di samping mendemonstrasikan persenjataan canggih juga ditandai dengan gegap gempitanya siaran langsung TV ke seluruh penjuru dunia dari medan perang yang ditayangkan jaringan TV intemasional CNN (Cable News Network) dan kemudian melambungkan nama wartawannya, Peter Amett. Siaran semacam itu sekarang menjadi mode yang menyebabkan tidak ada lagi beda jarak waktu antara sumber berita dengan konsumen berita. Sebenamya hal ini dapatlah dikatakan sebagai revolusi dalam media massa. Hal ini kemudian memicu pemasangan parabola di seluruh tanah air. Begitu juga dengan dunia pos. Nampaknya masa pengiriman surat melalui jasa pos yang memakan waktu berhari-hari bahkan minggu dan bulan berangsur-angsur akan mulai berkurang. Bagi rumah tangga yang dilengkapi maraknya electronic mail (E-mail). Saat ini di Indonesia jaringan Internet mungkin hanya bisa diakses melalui perusahaan ataupun perguruan tinggi. Namun bila melihat kecenderungan yang makin baik dalam prasarana telekomunikasi (telepon dan radio), pada beberapa tahun ke depan pengguna jasa Intemet akan terus meningkat. Atau dengan menggunakan ungkapan Jhon Naisbitt we are moving toward the capability to communicate anything to anyone, anywhere, by anyform voice, data, text, or image at the speed of light. Kita sedang bergerak ke arah kemampuan mengkomunikasi apapun kepada siapapun, dimanapun, berbentuk apapun suara, data, tulisan, atau gambar/ citra dengan kecepatan cahaya. Dan dalam kecenderungan seperti itu nampaknya yang akan dilindas oleh jalan raya informasi adalah jasa pos. Diperlukan adanya antisipasi untuk alih fungsi jika jasa pos akan digantikan surat elektronik.

\section{Era Informasi}

Majalah Time edisi 17 Juli 1995 memuat berita utama tentang teknologi masa depan. Kata kunci dari laporan adalah percepatan atau acceleration. Melalui suatu analogi dibandingkan antara seorang pembalap yang bergerak dengan kecepatan $275 \mathrm{~km} / \mathrm{jam}$ dapat dipercepat hanya dalam 
10 detik, kemudian kendaraan ruang angkasa dengan $28.000 \mathrm{~km} / \mathrm{jam}$ ditempuh dalam 8 menit. Namun hal itu masih kalah cepat dengan percepatan teknologi. Diperlukan 2 juta tahun bagi manusia untuk menemukan roda, dan hanya 5 ribu tahun untuk menemukan mesin uap untuk menggerakan roda. Komputer pertama memenuhi seluruh ruang dan dibutuhkan hanya 35 tahun menjadi seukuran dekstop, dan kurang dari sepuluh tahun untuk menjadi laptop. Bagaimana dengan masa depan; teknologi manakah yang akan mengisi dunia kita? Ada sepuluh jenis teknologi yang akan mengantarkan peradaban manusia memasuki abad 21 . Teknologi yang dimaksud adalah kendaraan dengan bahan bakar hidrogen, superkonduktor suhu-tinggi, rekayasa genetika, bionik, telpon pribadi universal, komputer yang dibangkitkan suara, nanoteknologi, eléktronika optik, virtual reality (VR) dan bahan baru. Dari kesepuluh teknologi tersebut separuhnya sangat terkait erat dengan dunia informasi. Menurut Toffler, informasi adalah data yang telah memasuki skema katagorisasi dan klasifikasi atau pola lainnya. Dan bila informasi ini diolah dan dihaluskan menjadi pernyataan-pernyataan umum akan berubah menjadi pengetahuan.

Teori informasi adalah cabang dari sibernetika yang mencoba untuk mendefinisikan banyaknya informasi yang diperlukan untuk mengontrol suatu proses dengan kompleksitas tertentu. Sedangkan sibernetika adalah teori tentang komunikasi dan mekanisme kontrol dalam makhluk hidup ataupun mesin. Dan teknologi informasi berkait erat dengan seluk beluk teknologi komunikasi dan komputer serta pengelolaannya. Jantung dari revolúsi-siber (cyberrevolution) tentulah komputer. Pada tahun 1994 masyarakat membelanjakan uangnya untuk komputer Rp. 16 trilyun, hanya berbeda sedikit dengan yang dibelanjakan untuk TV (Rp. 16,6 trilyun). Jumlah komputerdi Indonesia diperkirakan sekitar 1,5 juta buah. Dan bila harga ratarata komputer Rp. 2 juta, maka jumlah uang yang terpakai sekitar Rp 3 trilyun. Suatu jumlah yang spektakuler.

Ciri dari infrastrukturelektronik yang menjadi sandaran ekonomi maju adalah interaktivitas, mobilitas, dapat bertukar (convertibility), berhubungan, ubiquity dan globalisasi.Ubikuatisasi adalah penyebaran sistematis sistem media baru ke seluruh dunia dan singgah pada setiap lapisan ekonomi masyarakat. Ada hukum ubikuitas yang menyatakan bahwa keuntungan (insentif) komersial maupun politik yang kuat akan membangkitkan ketersediaan infrastruktur elektronik baru. Insentifitulah nampaknya yang diusahakan secara besarbesaran oleh perusahaan AT \& $\mathrm{T}$. IBM, Motorola, dan tertunya Microsoft yang dimiliki Bill Gates dengan kekayaan hampir Rp. 20 trilyun. Era informași ditandai dengan keterbukaan. Dalam era ini sangat sukar bagi pemerintah atau para pendukungnya untuk mengelola ide, imaginery, data, informasi maupun pengetahuan sebagaimana yang permah dilakukannya.

Untuk menghubungkan satu komputerdengan lainnya dilakukan melalui kabel telpon. Dan kabel yang sangat berperan adalah sert optik. Ambisi Jepang untuk menghubungkan setiap rumah dengan kabel tersebut diharapkan selesai pada tahun 2010. Di bagian dunia lain pun usaha yang 
sama sedang dilakukan. Maka planet buki kita diibaratkan dibungkus dengan kabel serat optik. It is a Wired, wired world. Para ahli kemudian membenarkan ramalan

- Marshall McLuhan tentang akan terbentuknya desa global. Dalam era informasi ini telah diperkenankan kosa kata yang sangat baru yaitu ruangsiber (cyberspace). Kosa kata ini mulai memenuhi halaman media massa. Pertama kali digunakan pada tahun 1984 oleh novelis Kanada William Gibson untuk menggambarkan ruang maya yang tercipta bila seseorang berhubungan dengan komputer telah diambil alih oleh pengguna informasi. Secara sederhana ruangsiber dapatlah dibayangkan sebagai suatu ruang yang tercipta bila kita berhubungan melalui telpon. Dan begitu pula ruang semacam dapat berbentuk bila beberapa komputer dihubungkan melalui suatu jaringan.
Memang pada dasamya ruang tiga dimensi yang kita alami seringkali adalah imaginasi. Sama halnya ketika kita menonton film atau TV, dimana kita merasa terlibat. Hanya saja dalam ruangsiber kita dapat berperan serta secara aktif (interaktif). Menyusul diperkenalkannya istilah cyberspace, istilah semacam seperti cybertribes, cyberporn, cyberscope, cybersex, cỷbermiall dan lainlain bermunculan.

Sentuhan revolusi informasi dalam kehidupan kesehariankita diantaranya dapat diilustrasikan pada gambar 1. Pada gambar tersebut banyak hal dapat diakses seperti perbankan, E-mail, forum, TV 24 jam, pelacakan film, dunia anak-anak, permainan informasi TV, pendidikan, olah raga, informasi cuaca, berita (misal koran Republik), majalah, bahan rujukan, sigi (polling) dan iklan.

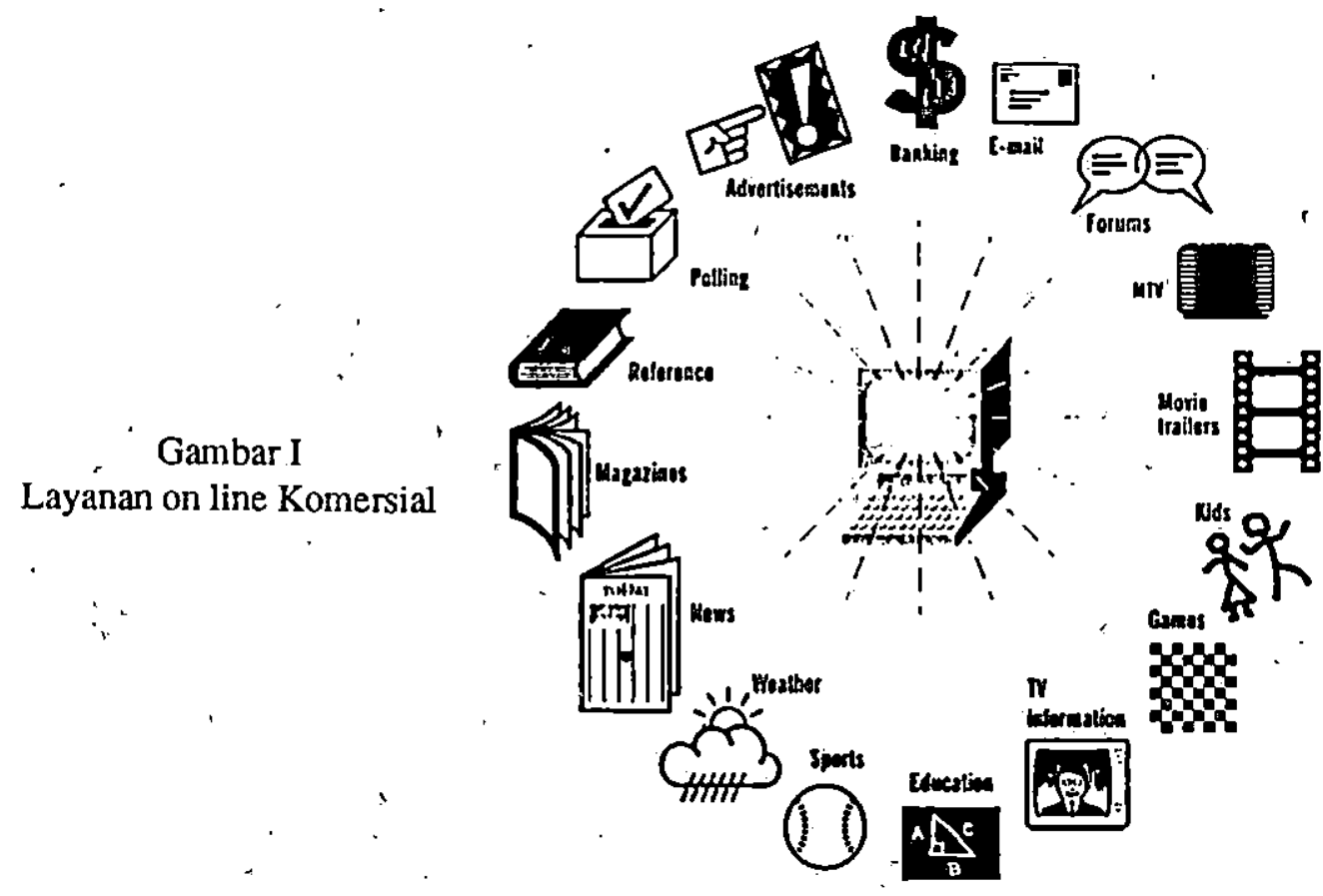




\section{Kesenjangan Informasi}

Apa yang digambarkan di depan adalah pencapaian positif. Adanya kemajuan dalam teknologi informasi. diharapkan' dapat 'mempermudah masyarákat dalam hidup. Namun seperti halnya dalam sisi kehidupan lainnya antara suatu kelompok masyarakat dengan yang lain ternyata ăda perbedaan dalam mengakses informasi. Karena itu ada kelompok yang disebut kaya-informasi (info-rich) dan miskin informasi (infopoor). Sehingga terbentuklah suatu jurang informasi. Hal ini terjadi antar kawasan. - Misalnya Eropa Barat, Amerika Utara dan Jepang termasuk kawasan kaya-informasi. Sementara Afrika secara keseluruhan miskin informasî. Kawasan Asia berada di kedua ekstrim tersebut. Untuk menghadapi perdagangan bebas kesenjangan tersebut tidakmenguntungkan. Untukitulah sedang diusahakan pengembangan infrastruktur elektronik. Ibarat jalan, dimana kendaraan berlalu lalang, maka melalui infrastruktur elektronik yang disebut electronic highway atau infobahn informasi apapun disebarkan. Adanya kesenjangàn dapat menciptakan .ketegangan. Seperti halnya yang terjadi beberapa saat yang lalu antara AS dan Cina. AS menuduh Cina melakukan pelanggaran hak cipta, sehingga AS menerapkan sangsi perdagangan terhadap Cina. Di Indonesia harga software relatif sangat murah, bahkan bisa gratis bila kitā membeli perangkat komputer. Nampaknya hal ini sulit dihindari karena kemampuan' beli masyarakat yang masih rendah. Bila software dijual dengan harga mahal seperti di negara asalnya, maka pemasyarakatan komputer akah terhambat.
Hal lain adalah kesenjangan dalam sumberdaya manusiaterdidik dàlàm bidang informasi. Bahwa telah terjadi demam informasi/komputer di Indonesia dapat dilihat dari menjamurnya persewaan komputer. Namun keinginan yang besar untuk mengusai komputer tidak disertai penyediaan SDM yang memadai. Di UGM misalnya doktor dalam bidang komputer masih belum mencapai 10 orang. Belum lagi kalau kita berbicara pada kualitas. Oleh karena itu kenyataan ini dapat menghambat usaha-usaha untuk menjadi negara dengan kategori kaya informasi.

\section{Perguruan Tinggi dalam Era Informasi}

Manusia harus dapat mengembangkan potensi yang ada dalam dirinya seoptimal mungkin. Dalam konteks tersebut secara sosiologis manusia disiapkan atau direkayasa melalui lembaga pendidikan. Dalam perkembangannya kemudian pendidikan cendenung menjadi masal dimana perhatian pada orang perorang sangạt rendah. Karenanya boleh jadi bakat-bakat tertentu tidak tampil ke, permukaan. Keberhasilan kinerja manusia ditentukan pula secara sosiologis. Dalam hal ini dibuat kesepakatan-kesepakatan. Misalnya kesepakatan tersebut berubah menjadi ukuran atau standar. Salah satu kesepakatan tersebut adalah human development index (HDI) yang menunjukkan ukuran terhadap tiga hal yaitu hàràpan hidup rata-rata; melek huruf latin dan GNP per kapita. Untuk data berdasar statistik akhir tahun 1980an, rangking tertinggi ditempati Jepang $(0,996)$, terendah Niger $(0,116)$, Malaysia $(0,800)$ dan Indonesia $(0,59.1)$ rangking 54 dari 130 negara. Bila data terakhir digunakan nampaknya rangking 
Indonesia cendcrung makin baik.

Tidak dapat dipungkiri bahwa pengembangan SDM di seluruh dunia seakan menempuh dua jalur utama yaitu pendidikan dan praktek kerja. Dalam kaitan ini dikenal dua pendapat. Pertama, pendidikan tidak terkait erat dengan lapangan kerja sedangkan yang kedua sebaliknya bahwa pendidikan harus terkait erat dengan lapangan kerja. Pendapat pertama mengacu pada alasan filosofis bahwa manusia bukan mesin. Biarkan manusia berkembang sendiri dan pendidikan hanyalah memberi bekal. Sementara yang kedua cenderung lebih pragmatik yaitu memenuhi tuntutan pasar tenaga kerja. Disadari bahwa ledakan lulusan pendidikan pada berbagai jenjang yang tidak dapat diserap pasar adalah suatu inefficiency. Walaupun sebenamya juga disadari bahwa lulusan tidak mungkin mengejar kebutuhan pasar yang senantiasa bergerak dan berkembang. Kebijakan Mendikbud saat ini yang disebut link \& match cenderung pada pendapat kedua, walaupun tetap mengindahkan pendapat pertama.

Newsweek edisi 5 Desember 1994 memuat wawancara menarik dengan Victor Riley seorang banker yang berhasil. Temanya adalah pendidikan tinggi masa depan dan kaitannya dengan perkembangan iptek mutakhir "High Tech andHigher Ed". Dikatakan bahwa pendidikan akan merasakan revolusi teknologi yang akan merubah kehidupan setiap orang di dunia. Revolusi iptek disini terutama dalam teknologi informasi. Pada dasarnya kerja adalah lebih ke arah memproses informasi daripada memproses bahan mentah. Berkat kemajuan teknologi informasi universitas pada masa mendatang lebih sebagai more learner-centered daripada class roombased. Yang diharapkan oleh pencari kerja (job seeker) adalah mahasiswa yang dewasa yang telah menetapkan jalur kariernya sedini mungkin. Bila PT tidak dapat mengantisipasi kecenderungan ini akan menjadi sejarah masa lampau. Sejalan dengan Riley, Paul Kennedy juga memperingatkan bahwa dalam menapak abad 21 dalam masyarakat global senantiasa. terjadi tarikan antara pendidikan dan katastrop (ledakan penduduk, kerusakan lingkungan dan kemampuan manusia membunuh dalam skala masal). Maka pendidikan terutama PT harus' lebih fleksibel. Akan terjadi ke luar-masuk mahasiswa yang frewensinya sangat tinggi. Di lingkungan kerja akan terjadi pergantian karier yang cepat, karenanya dibutuhkan lembaga pendidikan yang dapatmenyesuaikan dengan perubahan tersebut. Di masa depat yang terjadi misalnya mahasiswa kuliah dua tahun, masuk lapangan kerja, kuliah lagi, bekerja dan menyelesaikan kuliah akhimya. Hal ini menuntut perubàhan kurikulum dan administrasi yang luwes. Kecenderungan itu juga akan menyebabkan perubahan institusi sosial. Seperti yang disarankan Kennedy, pada masa mendatang yang diperlukan adalah kerja sama pada semua aras (masyarakat, suku, agama dan bangsa). Dalam kaitan ini agama dan institusi agama -berperan penting dalam memberikan arah dan pedoman bagi para anggotanya yang senantiasamengalami ketidakpastian hidup. Seperti yang terjadi di USA sekarang, kebanyakan rakyat cenderung menjadi makin konservatif terutama kaitannya dengan agama. Untuk itu diperlukan adanya 
pemerintah yang tanggap yang dapat menyesuaikan diri dan antisipatif terhadap perubahan-perubahan dan tantangantantangan masa depan yang makin rumit.

\section{Etos Kerja Islami dalam Era Informasi}

Di depan telah digambarkan tentang pengaruh teknologi informasi (TI) pada masyarakat. Pada sisi positif di mana TI dapat mempermudah kerja manusia, menaikkan produktivitas dan mempercepat pencapaian aplikasi suatu teknologi dalamkehidupan manusia. Dalam konteks ini Islam senantiasa sejalan. Daląm bahasa AlQur'an dikenal : Barangsiapa yang mengerjakan kebaikan seberat zarrah, niscaya dia akan melihat balasannya. Dan barangsiapa yang mengerjakan kejahatan seberat zarrah, niscaya dia akan melihat balasannya (Q. 99:7 dan 8). Bagainiana kebaikan dan keburukan diukur dengan zarrah? Apakah zarrah dapat dianalogikan dengan byte sebagai ukuran terkecil informasi? Apakah Allah mengandaikan pada kita tentang adanya kekekalan informasi. Bahwa infomasi itu tidak pemah musnah atau hilang. A pakah inimerupakan gambaran efisiensi informasi maksimal? Jadi dengan demikian dalam etos kerja Islam hendaknya dikembangkan suatu sikap untuk menggunakan serta memilih teknologi yang efisien dan bersih sesuai dengan kodrat manuśia.

Informasi menurut Islam tidak terbatas. Katakanlah: Kalau sekiranya lausanmenjaditinta untukmenuliskalimatkalimat Tuhanku, sungguh habislah lautan itu sebelum habis ditulis kalimat-kalimat Tuhanku, meskipun kami datangkan tambahan sebänyak itu. (Q 18:109). Dalam kaitan ini tentunya kita diminta untuk senantiasa 'optimis. 'Masih ada peluang ' untuk memperoleh informasi, walaupun sudah banyak dikelemukan oleh para ahli sebelumnya. Sikap pesimis seringkali dihinggapi oleh para peneliti dari negara berkembang melalui ungkapan klasik. Kita kan merangkak atau berjalan dalam mengembangkan ilmu, padahal peneliti dari ńegara maju berlari. Tidaklah kita akan selalu ketinggalan ? Namun harap diingat bahwa dengan membaiknya ekonomi Asia khususnya kawasan Asia Tenggara, peluang selalu terbuka. Dalam bahasa Magna Carta, ruangsiber merupakan ajakan peradaban yang paling benar dan tertinggi. Dan itulah . disebut fastabiul khoirat, berlomba beramal sebaik-baiknya.

Sikap kritis dan bijaksana dalam era informasi tetapdibutuhkan. Danjanganilah kamu mengikuti apa yang kamu tidak mempunyai pengetahuan tentangnya. Sesungguhnya pendengaran, peinglihatan dan hati, semuanya itu akán diminta. pertanggungan jaw'abnya. (Q, 17:36). Betapapun majunya teknologi informasi itu diminta Allahuntuk tidak lalai melainkan kritis dan arif. Karena semua pencapaian harus dipertanggung jawabkan. Apalagi diketahui bahwa kemajuan TI bisa disalahgunakan. Misalnya untuk pornografi (cyberporn) yang merusak moral terutama anak-anak di bawah umur. Begitu juga pembobolan bânk melalui akses on-line. Kemampuan yang dimiliki oleh seorang muslim senantiasa diarahkan kepada membawa salamah bagi umat manusia (rahmatan lil alamin). Para pengembang pengetahuan dan sistem komunikasi menyadari bahwa ilmunya tidaklah bebaskuman (antiseptik) ataupun netralkekuasaan. Dan tidak sebagaimana sering 
dituduhkan bahwa agama menjadi kendala dalam pengembangan ilmu maupun ekonomi. Justru sebaliknya sebagaimana

- dikutip dalam awal tulisan ini bahwa agama yang discbut sebagai salah satu faktor nonrational akan menjadi kunci sukses terbentuknya masyarakat modem dalam global ekonomi. Memang apa yang dikemukakan di atas belum menunjukkan kepada kepraktisan di lapangan. Karenanya etos kerja tersebut hanya dapat bermakna lebih luas lagi bila dipraktekkan terusmenerus dalam kehidupan nyata. Antara lain dalam kehidupan akademis. Bukankah ,memang ada satu kesatuan antara keyakinan dan praktek antara iman dan amal shaleh.

\section{Daftar Pustaka}

Al-Qur'an dan Terjemahnya. 1971. Departemen Agama RI. Jakarta

de la mothe.J and Dufour, P.R., 1995, TechnoGlobalism and the Challanges to Socience and Technology. Policy, Daedalus, Summer, 219-235

Toffer, A., 1990. Power Shift, Bantam Book. New York, USA.

Time. 1994, The Strange New. World of the Internet, July 23.

Time, 1995, Special Issue: Welcome to Cyberspace, May

Time, 1995. Cyberporn, July 3.

Time, 1995. Future Tech in Now, July 27.

Newsweek, 1995, Technology '95. February 27. Wallich, P., 1994. Wire Pirates, Sci.Am., Vol.270, March. 